\title{
Strategi Ibu dengan Peran Ganda dalam Membentuk Kemandirian Anak Usia Pra Sekolah
}

\author{
Ervin Nurul Affrida ${ }^{凶}$ \\ Program Studi PG-PAUD Universitas PGRI Adi Buana Surabaya
}

\begin{abstract}
Abstrak
Penelitian ini bertujuan untuk memahami pengalaman ibu dengan peran ganda dalam membentuk kemandirian anak. Ibu dengan peran ganda dalam penelitian ini dimaknai sebagai ibu yang memiliki peran menjadi ibu rumah tangga dan bekerja. Adanya peran ganda membuat peran sebagai ibu terbagi dengan peran sebagai wanita karir. Apalagi jika anak telah memasuki usia pra sekolah, peran ibu semakin diperlukan karena pada tahap ini anak berada pada masa keemasan,, jendela kesempatan, dan masa kritis (Depkes RI, 2010). Salah satu keteramplan yang harus dikembangkan yaitu kemandirian yang menjadi salah satu tujuan pendidikan karakter. Apalagi bagi ibu yang bekerja, membentuk kemandirian anak sejak usia dini dapat membantu anak untuk melakukan aktivitas sederhana seharihari ketika ibu sedang bekerja. Partisipan penelitian adalah empat orang ibu dengan peran ganda dan memiliki anak dengan rentang usia 3-6 tahun yang sedang mengikuti program di Kelompok Bermain/Taman Kanak-Kanak. Penggumpulan data menggunakan teknik wawancara mendalam kemudian dianalisis dengan metode Interpretative Phenomenological Analysis (IPA). Hasil penelitian menunjukkan bahwa pengalaman ibu dengan peran ganda dalam membentuk kemandirian anak melalui penggunaan pola asuh, pemberian contoh dan pendampingan pada anak dalam mengerjakan aktivitas yang bisa dilakukan anak secara mandiri, serta membiasakan anak untuk melakukan aktivitas sederhana sehari-hari untuk memenuhi kebutuhan diri sendiri.
\end{abstract}

Kata Kunci : Kemandirian, Strategi, Anak Usia Pra Sekolah

\begin{abstract}
This study aims for understand mothers experience with dual role to establish of independence child. Mother with dual role interpreted as a mother become housewife and work. The existence of dual role make the role as a mother divided by the role as a career woman. Especially if the child has entered pre-school age, the role of mother is needed because at this stage the child get in golden periode, window of opportunity, and critical period (Depker, 2010). One of the skills that should be developed is independence that became one of the goals of character education. Especially for working mothers, establishing independence of children from an early age can help children to perform simple daily activities when the mother at work. The study participants were four mothers with dual roles and have children with 3-6 year olds attending Play Group/Kindergarten Program. Data collection using indepth interview then analyzed by Interpretative Phenomenological Analysis (IPA) method. The result of the research shows that the mother experience with dual role in forming the independence of the children use of parenting, giving examples and mentoring to doing activities independently, and familiarize the children to perform simple daily activities to supply needs self.
\end{abstract}

Keywords: Independence Pre School Children, Strategy

@ Jurnal Obsesi Prodi PG-PAUD FIP UPTT 2017

$\triangle$ Corresponding author :

Address : Surabaya, Indonesia

Email : ervina@unipasby.ac.id 


\section{PENDAHULUAN}

Seiring dengan perkembangan ilmu pengetahuan dan teknologi banyak dijumpai fenomena wanita yang mulai turut berperan pada sektor publik salah satunya dengan bekerja. Dalam hal ini perempuan yang telah menikah, kemudian bekerja disebut memiliki peran ganda karena selain menjadi istri dan ibu rumah tangga, juga berperan sebagai wanita karir. Adanya peran ganda tersebut berdampak pada keterbatasan waktu yang dimiliki ibu dengan peran ganda, dibandingkan dengan ibu yang tidak bekerja yangdan memiliki rentang waktu lebih banyak bersama anak.

Bagi ibu dengan peran ganda yang memiliki anak usia pra sekolah, optimalisasi peran ibu berhubungan dengan tumbuh kembang anak. Hal ini disebabkan, anak pra sekolah yang berada pada rentang usia 3-6 tahun secara umum sedang mengikuti Kelompok Bermain, Taman Kanak-Kanak atau sejenisnya. Selain itu, anak juga mengalami pertumbuhan dan perkembangan yang pesat karena pada tahap ini anak berada pada masa keemasan (golden period), jendela kesempatan (window of opportunity), dan masa kritis (critical period) (Depkes RI, 2010).

Masa keemasan (golden periode) merupakan masa pertumbuhan dan perkembangan pesat pada otak yang berlangsung pada saat anak dalam kandungan hingga lahir sampai usia 4 (empat) tahun (Suyadi, 2010). Masa keemasan anak merupakan peluang untuk intervensi untuk memacu perkembangan anak. Selain itu, anak pra sekolah juga berada pada masa jendela kesempatan (window of opportunity) untuk memberikan stimulus terhadap perkembangan otak serta memodifikasi input yang akan diberikan pada anak. Anak pra sekolah juga berada pada masa kritis (critical period) karena perkembangan jaringan koneksi otak yang aktif dan mampu menyerap informasi serta memberikan respon terhadap stimulasistimulasi baru menjadikan anak berada pada masa kritis yang mengalami hambatan perkembangan jika tidak disertai oleh stimulus yang mendukung perkembangan anak.

Berdasarkan hasil penelitian dalam bidang neurologi menunjukkan bahwa sebanyak 50\% kecerdasan anak terbentuk pada 4 tahun pertama dalam kehidupannya (Suryanto, 2005). Pada kisaran rentang usia tersebut anak akan memasuki usia pra sekolah yaitu 3-6 tahun. Pada anak usia pra sekolah, salah satu potensi yang harus dikembangkan yaitu kemandirian karena anak mulai belajar memisahkan diri dari keluarga dan orang tua untuk memasuki lingkungan yang lebih luas dalam bentuk lingkungan Taman Kanak-Kanak atau Taman Bermain (Kartono, 1995). Selain itu, kemandirian menjadi salah satu karakter penting yang ditanamkan orang tua kepada anak sejak usia dini karena menjadi salah satu tujuan pendidikan karakter yang mencakup pengertian dari berbagai istilah seperti autonomy, independency, dan self reliance (Basyori, 2006).

Adapun kemandirian anak berdasarkan kerangka dasar kurikulum pendidikan anak usia dini tahun 2007 meliputi: (1) anak mampu berinteraksi; (2) mulai mematuhi aturan; (3) dapat mengendalikan emosi; (4) menunjukkan rasa percaya diri; dan (5) dapat menjaga diri sendiri. Selain itu pada anak usia pra sekolah terdapat indikator dalam mengikuti pendidikan pra sekolah, meliputi:

kemampuan kognitif yang memadai; (2) keterampilan berbahasa lisan dan keterampilan menulis; (3) artikulasi bahasa yang jelas dan dapat dipahami orang lain; (4) memiliki keterampilan motorik yang memadai; (5) mampu menolong diri sendiri; (6) memiliki keterampilan psikososial yang memadai; (7) kemampuan proses persepsi dan integratif (Lichtensein \& Ireton. 1984).

Salah satu indikator seperti yang dijelaskan diatas yaitu anak mempunyai keterampilan untuk menolong diri sendiri, hal ini sesuai dengan konsep kemandirian sehingga diharapkan anak mampu memenuhi kebutuhan diri sendiri. Adapun kemampuan menolong diri sendiri pada anak pra sekolah meliputi memakai baju, 
sepatu/sandal, menggosok gigi, mandi, menyisir rambut, makan/minum sendiri (Dariyo, 2007). Menurut Wiyani (2013), keterampilan dalam melakukan aktivitas sehari-hari sebagai indikator kemandirian anak meliputi makan tanpa disuap, memakai kaos kaki dan baju sendiri, buang air kecil/air besar sendiri, memakai baju/celana sendiri, merapikan mainan sendiri, dan mampu memilih bekal yang harus dibawa saat belajar di KB/TK. Kemandirian anak dalam bidang sosial dalam bentuk kemampuan memilih teman, keberanian belajar di kelas tanpa harus ditunggu oleh orang tua, dan bersedia berbagi bekal kepada teman ketika bermain.

Keterampilan untuk mandiri sangat penting diajarkan sejak usia dini agar anak menjadi individu yang tidak bergantung pada orang lain hingga remaja maupun dewasa. Apalagi pada anak usia pra sekolah dengan ibu yang bekerja, kemandirian anak perlu dibentuk untuk membantu anak melakukan aktivitas sederhana secara mandiri agar dapat memenuhi kebutuhannya sendiri saat ibu sedang bekerja. Kemandirian anak oleh ibu yang bekerja digambarkan dalam penelitian Geofanny (2016) yang menunjukkan hasil bahwa tingkat kemandirian anak yang diasuh oleh ibu yang bekerja lebih tinggi dibandingkan dengan anak yang diasuh oleh ibu yang tidak bekerja.

Selain itu, kemandirian penting untuk dilatihkan karena pada rentang usia 3-6 tahun anak berada pada tahap perkembangan psikososial inisiatif vs kesalahan (inititative vs guilt) yang berada pada rentang usia 3-6 tahun (Erickson, 1963). Pada tahap ini anak memiliki rasa ingin tahu yang tinggi sehingga belajar untuk merencanakan dan melaksanakan perilakunya. Perkembangan yang terhambat membuat anak takut untuk mengambil keputusan karena takut salah sehingga anak memiliki percaya diri yang rendah. Namun jika anak mampu melewati tahap perkembangan ini dengan baik, anak dapat memiliki kontrol diri dalam memilih tujuan hidupnya. Adapun sikap tersebut merupakan salah satu aspek kemandirian anak.

Menurut Hasan (2010), salah satu hal yang berpengaruh terhadap kemandirian anak adalah pola pengasuhan. Pentingnya pola asuh tercantum dalam hasil penelitian Joni (2015) yang menunjukkan bahwa terdapat hubungan antara pola asuh dengan perkembangan bahasa anak. Adapun jenis pola asuh meliputi pola asuh demokratis, otoriter, dan permisif (Hurlock, 1990). Adapun pola asuh yang diterapkan ibu yang bekerja bisa berbeda dengan pola asuh pada ibu rumah tangga yang mempunyai waktu penuh dalam mengasuh anak. Pada pola asuh otoriter, orang tua cenderung menetapkan standar yang harus dipatuhi anak. Sedangkan pola asuh permisif berbanding terbalik dengan pola asuh otoriter. Pada pola asuh permisif, orang tua cenderung memberikan kebebasan dan menuruti keinginan anak. Kemudian pola asuh demokratis yang menjadikan kepentingan anak sebagai prioritas utama namun diikuti dengan kontrol yang realistis dari orang tua.

Anak usia pra sekolah yang terlatih dengan baik oleh orang tua di rumah, dalam hal ini ibu yang bekerja akan dapat melakukan kegiatan sederhana dalam kehidupan sehari-hari secara mandiri yang bertujuan untuk memenuhi kebutuhan diri sendiri. Namun, anak yang tidak terbiasa dilatih untuk mandiri, maka dapat berdampak pada ketergantungan terhadap orang lain, apalagi dengan ibu peran ganda yang harus membagi waktu dengan bekerja. Oleh karena itu penelitian yang menggunakan pendekatan fenomenologi ini bertujuan untuk mengidentifikasi strategi pola asuh yang digunakan ibu dengan peran ganda dalam membentuk kemandirian anak usia pra sekolah.

\section{METODE}

Penelitian ini menggunakan metode penelitian kualitatif karena memiliki cakupan yang luas (breath) dan kedalaman (depth) dalam mengungkap pengalamanpengalaman individu. Adapun penelitian kualitatif mempunyai beberapa jenis pendekatan, dalam penelitian ini jenis 
pendekatan yang digunakan adalah fenomenologi. Menurut Steubert dan Carpenter (2011), pendekatan fenomenologi sebagai salah satu pendekatan kualitatif yang kritis dalam menggali fenomena pengalaman individu secara sistematis, dalam hal ini pengalaman ibu dengan peran ganda dalam membentuk kemandirian anak.

Pendekatan fenomenologi dalam penelitian ini berorientasi pada dua asumsi yaitu: (1) setiap pengalaman individu merupakan suatu ekspresi dari kesadaran yang menimbulkan pemaknaan yang bersifat subyektif; dan (2) setiap bentuk kesadaran identik dengan kesadaran akan sesuatu yang dialami (Smith \& Osborn, 2007). Berdasarkan asumsi tersebut dapat disimpulkan bahwa setiap ibu dengan peran ganda mempunyai pengalaman yang berbeda-beda dalam membentuk kemandirian anak. Adapun pengalaman dalam membentuk kemandirian anak tersebut juga dimaknai secara berbedabeda.

Unit analisis merupakan entitas yang menjadi fokus dalam penelitian (Boyazsis, 1998). Adapun unit analisis dalam penelitian ini adalah pengalaman ibu dengan peran ganda dalam membentuk kemandirian anak. Partisipan dalam penelitian dipilih menggunakan teknik purposive sampling, yaitu penentuan subjek/partisipan penelitian dengan pertimbangan dan tujuan tertentu (Sugiyono, 2015). Adapun kriteria partisipan dalam penelitian ini antara lain: (1) ibu dengan peran ganda, yaitu selain bekerja juga mengasuh anak secara mandiri di luar aktivitas karirnya, baik di sektor formal maupun informal; (2) ibu dengan peran ganda yang memiliki anak usia pra sekolah dan sedang mengikuti program Kelompok Bermain/Taman Kanak-Kanak, dan atau sejenisnya.

Teknik pengumpulan data yang digunakan adalah wawancara mendalam (in depth interview). In depth dalam penelitian ini bertujuan untuk mendalami makna yang mendalam untuk mendapatkan pemahaman yang mendetail tentang pengalaman ibu dengan peran ganda dalam membentuk kemandirian anak. Adapun pengorganisasian data penelitian dilakukan dengan mendokumentasikan, menyimpan data, dan analisis yang berkaitan dengan penyelesaian penelitian (Higlen \& Finey, dalam Poerwandari, 2005). Kemudian data yang diperoleh melalui wawancara mendalam dianalisis dengan cara Interpretative Phenomenological Analysis (IPA). Menurut Smith dan Osborn (2007), tahap-tahap analisisnya sebagai berikut: (1) reading and re-reading; (2) initial noting; (3) developing emergent themes; (4) searching for connection a cross emergent themes; (5) moving the next cases; dan (6) looking for patterns across cases. Teknik pemantapan kredibilitas penelitian menggunakan member check dengan prosedur sebagai berikut: (1) melakukan wawancara awal pada setiap partisipan sehingga memperoleh data awal; dan (2) melakukan klarifikasi pada waancara selanjutnya untuk menyamakan persepsi dengan partisipan.

\section{HASIL DAN PEMBAHASAN}

Ibu dengan peran ganda dalam penelitian ini dikonsepsikan sebagai ibu yang memiliki peran dualisme cultural yang memiliki konsep lingkungan domestik dan publik, yaitu selain menjadi ibu rumah tangga yang mengasuh anak secara mandiri, juga bekerja, baik di sektor formal maupun informal. Partisipan A merupakan ibu dengan peran ganda yang mempunyai anak berusia 3 tahun serta mengasuh anaknya secara mandiri di luar jam kerja sebagai tenaga pendidik. Ketika sedang menjalankan peran sebagai wanita karir, pengasuhan anak dipercayakan kepada instansi penyelenggara Kelompok Bermain yang dapat menyesuaikan dengan jam kerja partisipan. Partisipan B juga ibu dengan peran ganda yang mengasuh anaknya yang berumur 5 tahun secara mandiri di luar jam kerja. Saat bekerja free lance sebagai MUA profesional, pengasuhan anak dipercayakan kepada keluarga terdekat yaitu orang tua partisipan. Partisipan $\mathrm{C}$ serupa dengan partisipan $\mathrm{B}$ yang memiliki anak usia 5 tahun yang mengasuh anaknya secara 
mandiri di luar jam kerja sebagai pimpinan di salah satu bank swasta. Meskipun mempunyai asisten rumah tangga, namun partisipan $\mathrm{C}$ hanya mempercayakan pengasuhan anak kepada asisten tersebut saat sedang bekerja saja. Partisipan D yang bekerja sebagai wirausaha yang bergerak di bidang penjualan kebutuhan bahan makanan pokok dan keperluan rumah tangga serupa dengan partisipan A yang mempercayakan pengasuhan anaknya yang berusia 5 tahun di instansi penyelenggara Tempat Penitipan Anak sekaligus menyediakan fasilitas pendidikan Taman Kanak-Kanak.

Adanya peran ganda membuat peran sebagai ibu terbagi dengan peran sebagai wanita karir. Apalagi jika anak telah memasuki usia pra sekolah, peran ibu semakin diperlukan untuk membantu tumbuh kembang anak. Selain itu, anak usia pra sekolah juga mengalami pertumbuhan dan perkembangan yang pesat karena pada tahap ini anak berada pada masa keemasan (golden period), jendela kesempatan (window of opportunity), dan masa kritis (critical period) (Depkes RI, 2010). Salah satu potensi yang harus dikembangkan yaitu kemandirian yang menjadi salah satu tujuan pendidikan karakter. Adapun pendidikan karakter meurpakan proses pemberdayaan (empowering) potens peserta didik, proses humanisasi (humanizing), dan proses pembudayaan (civilizing) (Yenni, 2017).

Bagi ibu yang bekerja, membentuk kemandirian anak sejak usia dini dapat membantu anak untuk melakukan aktivitas sederhana sehari-hari untuk mencukupi kebutuhan sendiri ketika ibu sedang bekerja. Kemandirian anak usia pra sekolah dalam penelitian ini mencakup makna kemandirian dalam istilah autonomy dan independence. Kemandirian dalam istilah autonomy menggambarkan kemandirian sebagai self governing person yaitu kemampuan menguasai diri sendiri (Steinberg (1995). Independence dalam cakupan kemandirian berarti kemampuan dalam melakukan sendiri aktivitas hidup dan terlepas dari pengaruh kontrol orang lain, terutama orang tua (Steinberg, 1995).

Menurut Hasan (2010) menyatakan bahwa salah satu hal yang berpengaruh terhadap kemandirian anak adalah pola pengasuhan orang tua. Kemandirian anak usia pra sekolah dapat dilatih dengan membiarkan anak mempunyai pilihan dan mampu mengungkapkan pilihannya sejak dini (Hurlock, 1990). Pernyataan tersebut sesuai dengan jenis pola asuh demokratis yang memberikan kesempatan anak untuk menyampaikan keinginan diikuti dengan kontrol terhadap perilaku anak. Pola asuh otoriter berbeda dengan demokratis, karena pola asuh otoriter memberikan aturan standar orang tua yang harus dipatuhi anak. Sedangkan pola asuh permisif adalah pengasuhan yang memberikan kebebasan terhadap pemenuhan keinginan-keinginan anak.

Partisipan A yang memiliki jam kerja konsisten selalu berusaha mengasuh anaknya secara mandiri di luar jam bekerja. Hal ini dimanfaatkan partisipan untuk membangun bonding dengan anak, karena intensitas waktu bertemu dengan anak yang berkurang karena bekerja. Selain itu waktu yang singkat untuk bertemu dengan anak dimanfaatkan partisipan untuk berkomunikasi dengan mendengarkan keinginan/keluhan anak, mengajak anak mencari solusi dari keluhannya, membuat dan mengingatkan hal-hal yang seharusnya dilakukan sendiri oleh anak saat ibu sedang bekerja. Anak partisipan yang baru berusia 3 tahun dilatih untuk mandiri ketika makan dengan memilih menu makanan sendiri dan makan tanpa disuap, memberitahukan kepada ibu atau orang terdekat saat ingin buang air kecil/besar,

Partisipan B berbeda dengan partisipan A karena memiliki jam kerja free lance sehingga waktu kebersamaan dengan anak tidak tentu, kadang singkat karena harus berhari-hari karena pekerjaan di luar kota namun kadang juga memiliki waktu yang panjang sehingga dapat mengasuh anak secara mandiri jika sedang tidak ada jadwal bekerja. Partisipan membentuk kemandirian anak melalui 
pembiasaan anak untuk melakukan aktivitas sederhana untuk keperluan diri sendiri secara mandiri. Waktu yang ada bersama anak digunakan partisipan untuk memberikan contoh pada anak aktivitas yang harus dapat dilakukan anak ketika ditinggal bekerja seperti menggunakan baju sendiri, mengambil makanan dan tidak disuap, meletakkan peralatan sekolah di tempat yang disediakan, dan bersih diri seperti mencuci tangan, kaki, dan mandi.. Selain itu partisipan juga selalu melakukan komunikasi dengan anak, baik dalam bentuk mendengarkan dan merespon keinginan anak, dan yang terpenting mendengarkan cerita-cerita anak tentang kegiatannya sehari-hari. Selain itu setiap pulang bekerja dari luar kota, partisipan selalu membawakan buah tangan sebagai rewards untuk anaknya yang ditinggal bekerja.

Partisipan $\mathrm{C}$ memiliki jam kerja yang cukup konsisten seperti partisipan A. Namun partisipan $\mathrm{C}$ memiliki rentang kerja waktu yang lebih lama daripada partisipan A. Dalam melatih kemandirian anak, partisipan $\mathrm{C}$ bekerja sama dengan asisten rumah tangga yang mengasuh anaknya selama bekerja. Partisipan C selalu mengontrol aktivitas anaknya meskipun sedang bekerja, dan menganjurkan pengasuh anaknya untuk membiarkan anaknya melakukan aktivitas sederhana secara mandiri untuk memenuhi kebutuhan diri sendiri. Selain itu, setiap selesai bekerja partisipan selalu menyempatkan waktu untuk mendengarkan cerita tentang kegiatan yang dilakukan oleh anaknya sehari-hari. Keterbukaan dan sikap yang hangat selalu dibiasakan partisipan sejak dini kepada anaknya, hal tersebut digunakan partisipan agar anaknya terbuka untuk mengutarakan pendapatnya. Selain itu adanya keterbukaan dalam komunikasi memudahkan partisipan untuk mengontrol perilaku pengasuh kepada anaknya ketika sedang ditinggal bekerja.

Partisipan D memiliki jam kerja yang cukup panjang dibandingkan dengan partisipan lainnya. Partisipan memiliki rentang waktu kerja dari jam 05.30-15.00
WIB. Namun meskipun memiliki jam kerja yang cukup panjang, secara rutin partisipan menjemput anaknya setelah jam belajar Taman Kanak-Kanak. Hanya waktu-waktu tertentu ketika partisipan memasok barang dagangan saja anaknya diasuh di Tempat Penitipan Anak. Meskipun sedang bekerja dan membawa anak di tempat bekerja dimudahkan karena partisipan memiliki pegawai yang memadai. Untuk memodifikasi lingkungan kerja yang ramah untuk tempat bermain anaknya sepulang sekolah, partisipan menyediakan ruangan khusus. Di ruangan tersebut partisipan biasanya melakukan aktivitas bercerita dengan anak untuk menanyakan kegiatan yang telah dilakukan di sekolah. Selain itu partisipan juga melatih anaknya untuk melakukan aktivitas bantu diri secara mandiri, seperti melepas sepatu dan kaos kaki, berangkat mencuci kaki dan tangan sendiri, memilih dan mengambil menu makanan sendiri, dan pergi beristirahat di ruangan yang didesain khusus oleh partisipan untuk anaknya.

\section{PENUTUP \\ Simpulan}

Berdasarkan hasil penelitian dapat disimpulkan bahwa kemandirian anak usia pra sekolah dibentuk melalui penggunaan pola asuh, pemberian contoh dan pendampingan pada anak dalam mengerjakan aktivitas yang bisa dilakukan anak secara mandiri, serta membiasakan anak untuk melakukan aktivitas sederhana sehari-hari untuk memenuhi kebutuhan diri sendiri.

Temuan lain dalam penelitian ini menunjukkan bahwa ibu dengan peran ganda menggunakan komunikasi yang efektif untuk membangun bonding dengan anak karena singkatnya waktu untuk bersama anak. Komunikasi tersebut biasa dilakukan dengan mendengarkan cerita anak tentang aktivitas yang dilakukan dalam hari ini, mendengarkan keluhan anak, meminta anak menyampaikan keinginanya, dan memberikan respon terhadap cerita anak. 


\section{Saran}

Adapun saran bagi penelitian selanjutnya yaitu lebih merincikan cakupan kriteria kemandirian yang harus dicapai pada anak usia pra sekolah agar hasil penelitian dapat menggambarkan bentuk kemandirian anak yang lebih spesifik.

\section{UCAPAN TERIMA KASIH}

Terima kasih penulis sampaikan kepada Tim Editor Jurnal Obsesi yang telah memberikan kesempatan sehingga jurnal ini dapat diterbitkan. Ucapan terima kasih juga penulis sampaikan kepada reviewer yang bersedia memberikan masukan sehingga jurnal ini dapat lebih baik. Untuk segenap jajaran Pimpinan Universitas PGRI Adi Buana Surabaya dan teman sejawat Dosen Program Studi PGPendidikan Anak Usia Dini Universitas PGRI Adi Buana Surabaya yang memberikan semangat dalam penulisan ini sehingga dapat terselesaikan dengan tepat waktu.

\section{DAFTAR PUSTAKA}

Bashori, K. (2006). Psikologi Keluarga Sakinah. Yogyakarta: Suara Muhammadiyah.

Boyatzis, R.E. (1998). Transpforming Qualitative Information: Thematic Analysis and Code Development. Sage Publication.

Dariyo, A. (2007). Psikologi Perkembangan. Bandung: PT Refika Aditama.

Dinas Pendiidkan Nasional. (2006). Permendiknas Nomor 58 Tahun 2009 Tentang Standar Pendidikan Anak Usia Dini 9PAUD). Jakarta: Depdiknas.

Depkes RI. (2010). Profil Kesehatan Indonesia. Jakarta: Depkes RI.

Elisabeth, B. Hurlock. (1990). Psikologi Perkembangan. Edisi 5. Jakarta: Erlangga.

Erickson, EH. (1963). Childhood \& Society. Edisi Kedua. New York: Norton.

Geofanny, R. (2016). Perbedaan Kemandirian Anak Usia Dini Ditinjau Dari Ibu yang Bekerja dan Tidak Bekerja. Jurnal Psikoborneo. Vol. 4 Nomor 4, 2016: 711721.

Hasan, M. (2010). Pendidikan Anak Usia Dini. Yogyakarta: Diva Press.

Joni, J. (2015). Hubungan Pola Asuh Orang Tua Terhadap Perkembangan Bahasa Anak
Pra Sekolah (3-5 Tahun) di PAUD AlHasanah Tahun 2014. Jurnal Obsesi: Journal of Eraly Childhood Education. Vol.1, Nomor: 1, 2015: 42-48.

Kartono, K. (1995). Psikologi Anak 9Psikologi Perkembangan). Bandung: Mandar Maju.

Pusat Kurikulum Balitbang Depdiknas. 2007. Kerangka Dasar Kurikulum Pendidikan Anak Usia Dini. Departemen Pendidikan Nasional.

Peraturan Pemerintah Republik Indonesia. Undang-Undang Nomor 20 Tahun 2003

Tentang Sistem Pendidikan Nasional.

Poerwandari, E.K. (2005). Pendekatan Kualitatif untuk Penelitian Perilaku Manusia. Jakarta: Lembaga Pengembangan Sarana Pengukuran dan Pendidikan Psikologi Fakultas Psikologi Universitas Indonesia.

Smith, J. A., \& Osborn, M. (2007). Interpretative Phenomenological Analysis. In J. A. Smith (Ed.), Qualitative Psychology: Practical Guide to Research Method. London : SAGE Publications.

Steinberg, Laurence. (1995). Adolescene Sanfrancisco : McGraw-Hill Inc.

Streubert, H. J. \& Carpenter, D. R. (2011). Qualitative Research in Nursing Advancing the Humanistic Imperative, 5th. Philadephia: Lippincot William \& Wilkins A Wolters Kluwer Company.

Sugiyono. (2015). Metode Penelitian Kombinasi (Mixed Methode). Bandung: Alfabeta.

Suryanto, S. (2005). Dasar-dasar Pendidikan Anak Usia Dini. Yogyakarta: Hikayat Publishing.

Surya, Y.F. (2017). Penggunaan Model dan Pendekatan Pembelajaran Pendidikan Karakter Abad 21 pada Anak Usia Dini. Jurnal Obsesi: Journal of Early Childhood Education. Vol. 1 Nomor:1, 2017: 52-61.

Suyadi. (2010). Psikologi Belajar Anak Usia Dini. Yogyakarta : Pedagogia.

Wiyani, N. A. 2012. Bina Karakter Anak Usia Dini: Panduan Orangtua dan Guru Dalam Membentuk Kemandirian dan Kedisiplinan Anak. Yogyakarta: Ar-ruzz Media. 